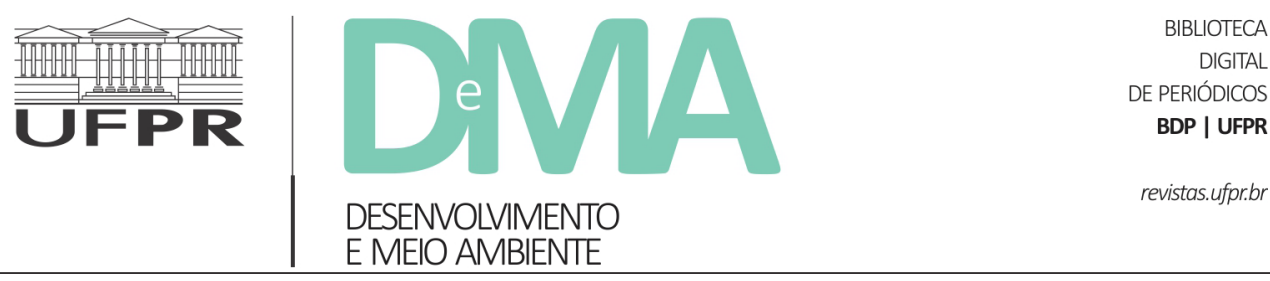

\title{
Flexibilização da regulação de agrotóxicos enquanto oportunidade para a (necro)política brasileira: avanços do agronegócio e retrocessos para a saúde e o ambiente
}

\section{Flexibilization of the pesticide regulatory policy as an opportunity for Brazilian (necro)politics: advances in agribusiness and setbacks for health and the environment}

\author{
Aline Monte GURGEL ${ }^{1 *}$, Clenio Azevedo GUEDES ${ }^{2}$, Karen FRIEDRICH ${ }^{3}$ \\ ${ }^{1}$ Instituto Aggeu Magalhães (IAM), Fundação Oswaldo Cruz (Fiocruz), Recife, PE, Brasil. \\ ${ }^{2}$ Programa de Pós-graduação em Desenvolvimento e Meio Ambiente (Prodema), Universidade Federal de Pernambuco (UFPE), Recife, PE, Brasil. \\ ${ }^{3}$ Escola Nacional de Saúde Pública Sergio Arouca (Ensp), Fundação Oswaldo Cruz (Fiocruz), Rio de Janeiro, RJ, Brasil. \\ *E-mail de contato: aline.gurgel@fiocruz.br
}

Artigo recebido em 1 de fevereiro de 2021, versão final aceita em 14 de junho de 2021, publicado em 30 de junho de 2021.

RESUMO: O modelo químico-dependente imposto pelo agronegócio expõe a sociedade brasileira a agrotóxicos associados a graves danos à saúde humana e ao ambiente. O avanço da pauta neoliberal no governo agravou o cenário de exposição a essas substâncias em decorrência do desmonte das políticas públicas que criam mecanismos de proteção. Neste sentido, este artigo coloca em foco a flexibilização de regras e normas de regulação de agrotóxicos no Brasil entre os anos de 2019 e 2020. Trata-se de um estudo descritivo e transversal que analisou normas, decisões judiciais e relatórios técnicos publicados no âmbito da União entre janeiro de 2019 e janeiro de 2021, mas com efeitos jurídicos retroativos até dezembro de 2020. Observou-se a liberação de um número recorde de agrotóxicos e a flexibilização de normativas que regulam o registro e o uso dessas substâncias no país, cujos impactos costumam atingir mais intensamente grupos populacionais em situação de maior vulnerabilidade. Argumenta-se que a associação entre o agronegócio e o aprofundamento de vulnerabilidades tem sido mediada por práticas de biopoder voltadas para atender aos interesses do capital financeiro, que determinam sobre quem deve recair os custos do modo capitalista de produção. Este cenário foi agravado com o avanço da pandemia do Covid-19 no país, configurando a necropolítica governamental, que se traduz em uma estratégia de eliminação de povos e comunidades tradicionais, negros, pobres e campesinos.

Palavras-chave: agrotóxicos; regulamentação governamental; biopoder; necropolítica; intoxicações.

Desenvolv. e Meio Ambiente usa uma Licença Creative Commons - Atribuição-NãoComercial-SemDerivações 4.0 Internacional 
ABSTRACT: The chemical-dependent model imposed by agribusiness exposes Brazilian society to pesticides associated with dangerous effects on human health and the environment. The hastening of the neoliberal agenda in the government worsens the pesticide exposure due to policy dismantling that creates protective mechanisms. Thus, this article focuses on Brazilian pesticide regulatory policy dismantling from 2019 to 2020. This descriptive cross-sectional study analyzed statutes, court decisions, documents, and technical reports published between January 2019 and January 2021, but with legal effects until December 2020. We observed the release of an unprecedented number of pesticides and the easing of Brazilian regulatory statutes, whose impacts affect intensely vulnerable groups. It is pointed out that biopower practices mediate the association between agribusiness and deepening of vulnerabilities, which serve the interests of financial capital and determine who should bear the costs of the capitalist mode of production. The Covid-19 pandemic in Brazil worsens this situation, expressing the government necropolitics, which reveals itself as a strategy to eradicate traditional peoples and communities, blacks, poor and rural populations.

Keywords: pesticides; government regulation; biopower; necropolitics; poisoning.

\section{Introdução: flexibilização normativa como estratégia do agronegócio}

Nos últimos anos, o Brasil se consolidou como um dos maiores produtores de commodities agrícolas do mundo, fortalecendo um modelo produtivo sustentado no uso de agrotóxicos, fertilizantes químicos e transgênicos (Gurgel et al., 2017). A hegemonia desse modo de produção é reflexo da condução da política do Estado brasileiro, pautada pelo neoliberalismo econômico e fundamentada na espoliação de direitos e na radicalização conservadora baseada no rentismo de curto prazo. Estas práticas reforçam a tendência de subordinação e heteronomia que marcam a posição do país no contexto geopolítico (Paulani, 2013). O modelo centrado no extrativismo e na exploração dos trabalhadores se intensifica no esteio do discurso neoliberal promovido pelos arautos do capitalismo mundializado, com graves consequências para a sociedade.
Essa forma de produção está associada à geração de iniquidades e injustiças, ao acúmulo de prejuízos fiscais e materiais, à perda de autonomia, à concentração fundiária, à expropriação de terras e recursos naturais, à expulsão e marginalização da população do campo, à contaminação ambiental e à promoção de doenças e agravos (Carneiro et al., 2015; Gurgel et al., 2018; Fiocruz, 2019a). Nesse cenário, o agronegócio emprega capital político para externalizar as consequências inerentes ao seu modelo de produção aos consumidores, governos, trabalhadores agrícolas, produtores e comunidades rurais (Wallace, 2020), cujos impactos são sentidos mais profundamente por grupos populacionais vulnerabilizados - como povos e comunidades tradicionais, populações do campo, gestantes, crianças e idosos (Carneiro et al., 2015).

As relações capitalistas do modo de produção do agronegócio avançam particularmente em países de economia periférica e caracterizam um "neoextrativismo exportador"1, hegemônico no Sul global (Bernardo, 2020). A expansão de empresas

${ }^{1} \mathrm{O}$ neoextrativismo pode ser definido como "um modelo de desenvolvimento focado no crescimento econômico e baseado na apropriação de recursos naturais, em redes produtivas pouco diversificadas e na inserção subordinada na nova divisão internacional do trabalho. O fenômeno vem sendo associado a diferentes tensões, sejam ligadas ao baixo crescimento econômico de longo prazo, sejam associadas a impactos sociais 
do agronegócio no Sul global tem como finalidade precípua a otimização dos lucros, já que a região se caracteriza por baixos custos na mobilização de mão-de-obra e na aquisição de terras (Wallace, 2020), além de legislações trabalhistas e de proteção ambiental mais frágeis. Diversas mudanças efetuadas em legislações ambientais, de regularização fundiária e reforma agrária (sobretudo no que diz respeito a demarcações de terras indígenas e quilombolas), de proteção dos direitos de trabalhadores e campesinos, ou mesmo de reformas das políticas curriculares, têm sido patrocinadas por grandes corporações atreladas à expansão do capital financeiro internacional (Gurgel et al., 2018). As leis trabalhistas e de proteção à saúde e ao ambiente são vistas como "entraves" à implementação desse modelo, prevalecendo a crença fetichista de que tudo o que se coloca na trilha de um crescimento econômico indefinido representa um obstáculo a ser transposto (Harvey, 2013).

A crescente pressão dos conglomerados econômicos de produção de agroquímicos, para atender às demandas do mercado de commodities agrícolas, tem resultado na supressão da função reguladora do Estado (Pelaez et al., 2010; Gurgel et al., 2017; Friedrich et al., 2021). É ampliada a tensão entre o modelo neodesenvolvimentista - um mito do desenvolvimento capitalista que tenta conciliar crescimento com equidade - e os direitos à saúde e a um ambiente equilibrado. No entanto, a expansão do agronegócio depende necessariamente do uso intensivo de agrotóxicos, expondo as populações a compostos associados a intoxicações agudas severas e à manifestação de problemas crônicos como câncer, mutagênese, teratogênese, manifestações neurotóxicas e outros, podendo levar à morte (Gurgel et al., 2017; 2018).

Se o avanço das políticas neoliberais, desde a década de 1990, favorece a expansão do agronegócio e a consolidação da inserção brasileira no modelo primário-exportador, mais recentemente a tendência de intensificação da pauta neoliberal no Brasil assumiu novos parâmetros. Como argumentam Lobato et al. (2019), a inédita associação entre extrema direita e liberalismo econômico no âmbito do governo Bolsonaro, com uma pauta conservadora sustentada por propostas liberais no campo econômico, culminaram em uma ampla reforma do Estado. Flexibilização, reforma, ajuste e austeridade passaram a ser palavras de ordem do atual governo, materializando-se no desmonte de direitos e conquistas.

Nesse contexto, os problemas associados ao modo de produção do agronegócio vêm se agravando pelos recentes desmontes das políticas públicas no país e, desde fevereiro de 2020, pela irrupção da pandemia de Covid- $19^{2}$. Além disso, a crise sanitária tem sido entendida como uma "oportunidade" para a implementação de outras medidas de flexibiliza-

e ambientais diversificados" (Milanez \& Santos, 2013, p. 119). O caráter exportador deve-se ao fato de que os produtos não processados, ou minimamente processados, extraídos dos territórios explorados são destinados fundamentalmente ao mercado internacional, atendendo às demandas dos países de economia central (Bernardo, 2020).

${ }^{2}$ A Covid-19 é uma doença provocada por um novo coronavírus, responsável pela síndrome respiratória aguda grave (severe acute respiratory syndrome coronavirus - SARS-CoV-2 ou 2019-nCoV), que surgiu em dezembro de 2019 em Wuhan, na China e espalhou-se rapidamente no mundo. A doença foi caracterizada pela Organização Mundial de Saúde como uma pandemia em 11 de março de 2020, sendo classificada como uma Emergência de Saúde Pública de Importância Internacional (OPAS, 2020). 
ção ${ }^{3}$, implicando na perda de direitos conquistados ao longo de décadas.

No Brasil - e em outros países de economia periférica de modo particular -, os efeitos da pandemia na saúde são agravados por desigualdades sociais, fragilização democrática, retrocessos nas políticas sociais e ambientais, insegurança alimentar e nutricional, presença de grandes contingentes populacionais com comorbidades, e exposição a agrotóxicos - dentre outras vulnerabilidades (Ortega \& Orsini, 2020). Dessa forma, as populações pobres, periféricas, os povos e comunidades tradicionais, os negros e as mulheres são afetados de forma mais grave (Reis-Filho \& Quinto, 2020; Wang \& Tang, 2020; Wenham et al., 2020).

Além disso, observa-se uma dinâmica de retroalimentação, na qual os impactos do agronegócio são agravados pela pandemia e podem, simultaneamente, ser entendidos como geradores de epidemias. Segundo Rob Wallace (2020, p. 527) "tanto a pecuária quanto a agricultura [intensiva] impulsionam o desmatamento e os empreendimentos que aumentam a taxa e o alcance taxonômico do transbordamento de patógenos: dos animais selvagens para os da pecuária e, destes, para os trabalhadores do setor". $\mathrm{O}$ autor destaca ainda que a íntima relação do modo de produção do agronegócio com o surgimento de novas pandemias deve-se às modificações genéticas e ao uso de agrotóxicos, que podem levar ao surgimento de patógenos super-resistentes; à perda da biodiversidade e à proliferação de espécies que podem causar doenças; ou mesmo à forma como os animais são criados (em espaços confinados e com homogeneização de raça, idade e sistema biológico), favorecendo o desenvolvimento de doenças e a disseminação de patógenos. Da mesma forma, o escoamento das mercadorias em um contexto de globalização e de exportação de commodities, pode fácil e rapidamente disseminar patógenos que, em outros cenários, permaneceriam confinados.

Considerando este quadro, o presente artigo busca analisar a flexibilização de regras e normas de regulação de agrotóxicos no Brasil no período de 2019 a 2020.

\section{Metodologia}

Trata-se de um estudo descritivo e transversal, com pesquisa documental centrada na análise de: (a) normas de natureza infraconstitucional (como decretos, leis, resoluções); (b) normas/atos editados por órgãos do poder executivo como o Ministério da Agricultura, Pecuária e Abastecimento (Mapa) ou por autarquias federais como a Agência Nacional de Vigilância Sanitária (Anvisa) e o Instituto Brasileiro do Meio Ambiente e dos Recursos Naturais Renováveis (Ibama) (a exemplo de instruções normativas, atos, resoluções, decisões colegiadas); (c) decisões judiciais do Supremo Tribunal Federal (STF) em sede de controle de constitucionalidade;

\footnotetext{
${ }^{3}$ Durante a "célebre" reunião ministerial de 22 de abril de 2020, o ministro do Meio Ambiente, Ricardo Salles, ponderou que o governo deveria aproveitar o momento em que o foco da sociedade e da mídia estava voltado para a Covid-19 para mudar regras ligadas à proteção ambiental e à área de agricultura, evitando aprovação do Congresso e processos na Justiça (STF, 2020). De acordo com o ministro: “A oportunidade que nós temos, que a imprensa está nos dando um pouco de alívio nos outros temas, é passar as reformas infralegais de desregulamentação, simplificação, todas as reformas. Então pra isso precisa ter um esforço nosso aqui enquanto estamos nesse momento de tranquilidade no aspecto de cobertura de imprensa, porque só fala de Covid, e ir passando a boiada e mudando todo o regramento e simplificando normas. (...) De Ministério da Agricultura, de Ministério de Meio Ambiente".
} 
e (d) documentos e relatórios técnicos produzidos pelo Mapa, Anvisa e Ibama.

Foram pesquisados documentos publicados entre janeiro de 2019 e janeiro de 2021, mas com efeitos jurídicos retroativos até dezembro de 2020, referentes a regras e normas de regulação de agrotóxicos no Brasil no âmbito da União. Os dados foram coletados entre outubro de 2020 e janeiro de 2021. As buscas foram realizadas no sítio eletrônico da Imprensa Nacional, onde é disponibilizado o Diário Oficial da União (DOU) (https://www.in.gov.br), do STF (http://portal.stf.jus.br), do Mapa (https:// www.gov.br/agricultura/pt-br), da Anvisa (https:// www.gov.br/anvisa/pt-br) e do Ibama (https:// www.gov.br/ibama/pt-br). Utilizou-se como termo de busca o descritor "agrotóxico". Nos sítios do STF e da Imprensa Nacional foram utilizadas as ferramentas de busca disponíveis, sendo incluídos os filtros referentes ao período analisado e aos tipos de documentos que foram objeto de pesquisa. Nos endereços das agências reguladoras o levantamento não obedeceu a nenhum padrão definido por não haver ferramentas específicas para busca dos documentos utilizados no presente estudo.

Os documentos encontrados foram organizados utilizando o Microsoft Excel 2016, de acordo com: fonte (órgão de origem), tipo de documento, mensagem geral, resumo e referência. Em seguida foi realizada a leitura completa de todos os documentos, que foi seguida da seleção, sistematização e análise do corpus da pesquisa.

\section{Principais mudanças na regulação e liberação de agrotóxicos impostas no Brasil nos primeiros dois anos do governo Bolsonaro}

No período de janeiro de 2019 a dezembro de 2020, foram aprovadas diversas medidas legais e infralegais que flexibilizam o registro e uso de agrotóxicos no Brasil, bem como aumentam o número de agrotóxicos com uso autorizado no país. Tais medidas buscam atender a uma agenda de fortalecimento do agronegócio, pautada no enfraquecimento do controle do Estado no âmbito da regulação de agrotóxicos. Diversas medidas vêm sendo implementadas diretamente pelo Executivo como uma forma de acelerar o processo ao evitar o cumprimento dos ritos legais exigidos para aprovação de leis contendo tais mudanças, que dependeriam da consulta ao Legislativo (Tabela 1).

Nesse período, destacam-se, em particular, a liberação do maior número de agrotóxicos no Brasil comparado a qualquer outro período, e a adoção de medidas legais e infralegais voltadas à "simplificação" de regras e normas que regulam o registro, a comercialização e o uso dessas substâncias no país.

Embora não tenha sido objetivo do presente estudo comparar os dois primeiros anos da gestão Bolsonaro com seus antecessores, é importante reconhecer que medidas favoráveis ao setor regulado ou que impliquem na fragilização da regulamentação de agrotóxicos também foram registradas em governos anteriores, conforme evidenciou Gurgel (2017) ao analisar a legislação de agrotóxicos entre 1923 e $2016^{4}$.

\footnotetext{
${ }^{4}$ A redução a zero das taxações incidentes na importação e na comercialização do mercado interno de fertilizantes e agrotóxicos, referentes às alíquotas da contribuição para o PIS/Pasep e da Contribuição para o Financiamento da Seguridade Social (Cofins) incidentes na importação
} 
TABELA 1 - Atos do governo federal no Executivo, Legislativo e Judiciário alterando a regulamentação e uso de agrotóxicos, $2019-2020$.

\begin{tabular}{|c|c|c|}
\hline Órgão & Ato & Resumo \\
\hline Mapa & Ato $\mathrm{n}^{\mathrm{o}} 1$, de 9 de janeiro de 2019 & Libera 18 produtos técnicos, 8 produtos formulados e 2 agentes biológicos \\
\hline Mapa & Ato $n^{\circ} 4$, de 17 de janeiro de 2019 & Libera 9 produtos técnicos, 1 produto formulado \\
\hline Mapa & Ato $\mathrm{n}^{\mathrm{o}} 7$, de 4 de fevereiro de 2019 & Libera 6 produtos técnicos, 13 produtos formulados \\
\hline Mapa & Ato $\mathrm{n}^{\circ} 10$, de 18 de fevereiro de 2019 & Libera 21 produtos técnicos, 6 produtos formulados e 2 agentes biológicos \\
\hline Mapa & Ato $\mathrm{n}^{\circ} 17$, de 19 de março de 2019 & Libera 8 produtos técnicos, 22 produtos formulados e 5 agentes biológicos \\
\hline Мapa & Ato $\mathrm{n}^{\circ} 24$, de 9 de abril de 2019 & $\begin{array}{l}\text { Libera } 4 \text { produtos técnicos equivalentes, } 19 \text { produtos formulados e } 8 \text { produtos técnicos equivalentes } \\
\text { clones }\end{array}$ \\
\hline Mapa & Ato $n^{\circ} 29$, de 29 de abril de 2019 & Libera 3 produtos técnicos, 10 produtos formulados, 1 agente biológico \\
\hline Mapa & Ato $\mathrm{n}^{\circ} 34$, de 16 de maio de 2019 & Libera 29 produtos técnicos e 2 produtos formulados \\
\hline Mapa & Ato $n^{\circ} 42$, de 19 de junho de 2019 & Libera 30 produtos técnicos, 10 produtos formulados e 2 agentes biológicos \\
\hline Mapa & Ato $n^{\circ} 48$, de 19 de junho de 2019 & Libera 18 produtos técnicos, 29 produtos formulados e 4 agentes biológicos \\
\hline Anvisa & RDC nº 294 , de 29 de julho de 2019 & $\begin{array}{l}\text { Critérios para avaliação e classificação toxicológica, priorização da análise e comparação da ação } \\
\text { toxicológica de agrotóxicos }\end{array}$ \\
\hline Anvisa & RDC n ${ }^{\circ} 295$, de 29 de julho de 2019 & Critérios para avaliação do risco dietético decorrente da exposição humana a resíduos de agrotóxicos \\
\hline Anvisa & $\mathrm{RDC}^{\circ}$ 296, de 29 de julho de 2019 & Dispõe sobre as informações toxicológicas para rótulos e bulas de agrotóxicos \\
\hline Mapa & Ato $\mathrm{n}^{\mathrm{o}} 62$, de 13 de setembro de 2019 & Libera 49 produtos técnicos, 14 produtos formulados \\
\hline Мара & Ato $\mathrm{n}^{\mathrm{o}} 70$, de 02 de outubro de 2019 & Libera 29 produtos técnicos, 18 produtos formulados e 10 agentes biológicos \\
\hline Mapa & Ato $\mathrm{n}^{\mathrm{o}} 82$, de 25 de novembro de 2019 & Libera 36 produtos técnicos, 9 produtos formulados e 12 agentes biológicos \\
\hline Anvisa & RDC nº 320, de 28 de novembro de 2019 & $\begin{array}{l}\text { Dispõe sobre a manutenção do ingrediente ativo Tiram em produtos agrotóxicos no País, bem como } \\
\text { determina medidas de mitigação de riscos à saúde e alterações no registro decorrentes da sua reava- } \\
\text { liação toxicológica }\end{array}$ \\
\hline Anvisa & Publicação de Relatório & $\begin{array}{l}\text { Programa Análise de Resíduos de Agrotóxicos em Alimentos. Resultados de amostras coletadas entre } \\
2017 \text { e } 2018\end{array}$ \\
\hline Presidência & Decreto $\mathrm{n}^{\circ} 10.178$, de 18 de dezembro de 2019 & $\begin{array}{l}\text { Regulamenta dispositivos da Lei n }{ }^{\circ} 13.874 \text {, de } 20 \text { de setembro de } 2019 \text {, para dispor sobre os critérios } \\
\text { e procedimentos para a classificação de risco de atividade econômica e para fixar o prazo para apro- } \\
\text { vação tácita de agrotóxicos }\end{array}$ \\
\hline Mapa & Ato $n^{\circ} 91$, de 26 de dezembro de 2019 & Libera 23 produtos técnicos, 9 produtos formulados e 4 agentes biológicos \\
\hline Mapa & Ato $\mathrm{n}^{\mathrm{o}} 12$, de 19 de fevereiro de 2020 & Libera 32 produtos técnicos \\
\hline
\end{tabular}

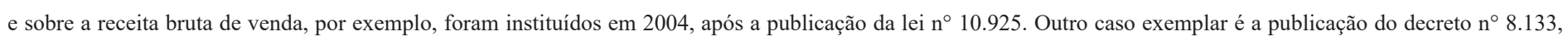

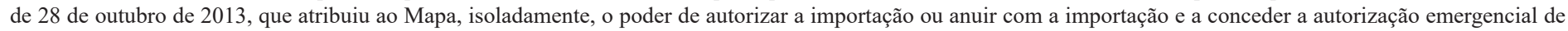

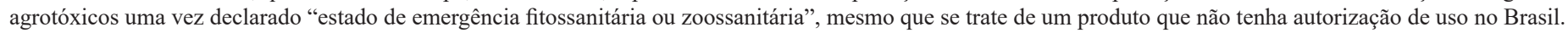




\begin{tabular}{|c|c|c|}
\hline Mapa & Ato $\mathrm{n}^{\mathrm{o}} 13$, de 19 de fevereiro de 2020 & Libera 14 produtos formulados e 2 agentes biológicos \\
\hline Mapa & Portaria $\mathrm{n}^{\mathrm{o}} 43$, de 21 de fevereiro de 2020 & Estabelece os prazos para aprovação tácita de agrotóxicos e outros atos (impugnada) \\
\hline Mapa & Ato $n^{\circ} 20$, de 23 de março de 2020 & Altera as classificações toxicológicas dos produtos formulados agrotóxicos e afins \\
\hline Mapa & Ato $n^{\circ} 22$, de 25 de março de 2020 & Libera 18 produtos técnicos \\
\hline Mapa & Ato $\mathrm{n}^{\mathrm{o}} 26$, de $1^{\circ}$ de abril de 2020 & Libera 28 produtos formulados e 18 agentes biológicos \\
\hline Mapa & Ato $\mathrm{n}^{\mathrm{o}} 28$, de 22 de abril de 2020 & Libera 16 produtos formulados \\
\hline Mapa & Ato $\mathrm{n}^{\mathrm{o}} 31$, de 4 de maio de 2020 & Libera 19 produtos formulados e 3 agentes biológicos \\
\hline Mapa & $\begin{array}{l}\text { Instrução Normativa } n^{\circ} 13 \text {, de } 8 \text { de abril de } \\
2020\end{array}$ & $\begin{array}{l}\text { Dispõe sobre a aplicação de fungicidas e óleo mineral com uso de aeronaves agrícolas na cultura da } \\
\text { banana }\end{array}$ \\
\hline Mapa & Ato $\mathrm{n}^{\mathrm{o}} 36$, de 5 de junho de 2020 & Libera 23 produtos formulados e 4 agentes biológicos \\
\hline STF & Julgamento ADPF 656 e 658 & $\begin{array}{l}\text { Concessão de medida cautelar para suspender prazos para liberação tácita de agrotóxicos após } 60 \\
\text { dias mesmo sem estudos de saúde e meio ambiente, cancelando efeitos de dispositivos da Portaria } \\
\text { 43/2020 do MAPA }\end{array}$ \\
\hline Mapa & Portaria $^{\circ} 208$, de 29 de junho de 2020 & $\begin{array}{l}\text { Estabelece as diretrizes para a elaboração do Plano de Supressão e as medidas emergenciais de con- } \\
\text { trole a serem aplicadas no caso de surtos da praga Schistocerca cancellata nos Estados do Rio Gran- } \\
\text { de do Sul e de Santa Catarina }\end{array}$ \\
\hline Mapa & Ato $\mathrm{n}^{\mathrm{o}} 39$, de 6 de julho de 2020 & Libera 21 produtos técnicos \\
\hline Mapa & Ato $n^{\circ} 43$, de 27 de julho de 2020 & Libera 26 produtos formulados e 12 agentes biológicos \\
\hline Mapa & Ato $n^{\circ} 46$, de 5 de agosto de 2020 & Libera 6 produtos formulados \\
\hline Mapa & Ato $\mathrm{n}^{\circ} 48$, de 17 de agosto de 2020 & Libera 18 produtos formulados e 10 agentes biológicos \\
\hline Mapa & Ato $\mathrm{n}^{\circ} 51$, de 3 de setembro de 2020 & Libera 14 produtos formulados \\
\hline Mapa & Ato $\mathrm{n}^{\mathrm{o}} 55$, de 21 de setembro de 2020 & Libera 27 produtos formulados e 4 agentes biológicos \\
\hline Conama & $\begin{array}{l}\text { Resolução Conama/MMA n }{ }^{\text {0 }} 499 \text {, de } 6 \text { de } \\
\text { outubro de } 2020\end{array}$ & $\begin{array}{l}\text { Dispõe sobre o licenciamento da atividade de coprocessamento de resíduos, incluindo de agrotóxi- } \\
\text { cos, em fornos rotativos de produção de clínquer (cimento) }\end{array}$ \\
\hline Anvisa & RDC n ${ }^{\circ} 428$, de 08 de outubro de 2020 & $\begin{array}{l}\text { Altera a RDC n }{ }^{\circ} 177 \text {, de } 21 \text { de setembro de } 2017 \text {, que dispõe sobre a proibição do ingrediente ativo } \\
\text { Paraquate em produtos agrotóxicos no país e sobre as medidas transitórias de mitigação de riscos, } \\
\text { para tratar da utilização dos estoques em posse dos agricultores brasileiros de produtos à base do } \\
\text { ingrediente ativo Paraquate }\end{array}$ \\
\hline Mapa & Ato $\mathrm{n}^{\mathrm{o}} 59$, de 19 de outubro de 2020 & Libera 12 produtos formulados \\
\hline Mapa & Ato $\mathrm{n}^{\circ} 60$, de 26 de outubro de 2020 & Libera 13 produtos formulados e 3 agentes biológicos \\
\hline Mapa & Ato $n^{\circ} 64$, de 18 de novembro de 2020 & Libera 21 produtos formulados \\
\hline Mapa & Ato $\mathrm{n}^{\circ} 65$, de 23 de novembro de 2020 & Libera 31 produtos formulados e 11 agentes biológicos \\
\hline
\end{tabular}




\begin{tabular}{|c|c|c|}
\hline Anvisa & RDC ${ }^{\circ} 441$ de 2 de dezembro de 2020 & $\begin{array}{l}\text { Manutenção do ingrediente ativo Glifosato em produtos agrotóxicos no País, determina medidas de } \\
\text { mitigação de riscos à saúde e alterações no registro decorrentes da sua reavaliação toxicológica }\end{array}$ \\
\hline Anvisa & $\mathrm{RDC} \mathrm{n}^{\circ} 442$, de 2 de dezembro de 2020 & $\begin{array}{l}\text { Manutenção do ingrediente ativo Abamectina em produtos agrotóxicos no País, determina medidas } \\
\text { de mitigação de riscos à saúde e alterações no registro decorrentes da sua reavaliação toxicológica }\end{array}$ \\
\hline Mapa & Ato $\mathrm{n}^{\circ} 70$, de 23 de dezembro de 2020 & Libera 37 produtos técnicos e 19 agentes biológicos \\
\hline Mapa & Ato $^{\circ} 71$, de 28 de dezembro de 2020 & Libera 32 produtos técnicos \\
\hline
\end{tabular}


Contudo as medidas que caracterizam a redução da esfera de atuação do Estado - e, consequentemente, a redução das medidas de proteção à saúde e ao ambiente -, concentram-se em anos recentes, sendo particularmente favorecidas pela conjuntura político-institucional estabelecida após o impeachment de Dilma Rousseff ${ }^{5}$, em 2016.

As principais mudanças na regulação de agrotóxicos no Brasil nos primeiros dois anos do governo Bolsonaro identificadas no presente estudo foram sistematizadas em subseções temáticas da seguinte forma: (3.1) Liberação de agrotóxicos; (3.2) Reavaliação toxicológica de agrotóxicos; (3.3) Mudanças nos procedimentos de avaliação de toxicidade, risco e comunicação de risco; (3.4) Liberação tácita de agrotóxicos; (3.5) Flexibilização das regras de pulverização aérea; (3.6) Liberação do uso de agrotóxicos proibidos no Brasil em casos de emergência fitossanitária; (3.7) Revisão da Portaria de Potabilidade da Água; e (3.8) Autorização da queima de resíduos de agrotóxicos em fornos de cimenteiras.

\subsection{Liberação de agrotóxicos}

Nos dois primeiros anos do governo Bolsonaro, foram liberados ao todo 997 agrotóxicos, número que corresponde à soma de todos os agentes que tiveram registro concedido e foram discriminados nos Atos do Mapa publicados nesse período. Esse número recorde corresponde à liberação de 419 produtos técnicos, 04 produtos técnicos equivalentes, 08 produtos técnicos equivalentes clones,
438 produtos formulados e 128 agentes biológicos de controle. A título de comparação, entre 2010 e 2015 - um intervalo temporal três vezes maior -, foram registrados 815 agrotóxicos, número inferior aos aprovados apenas na primeira metade da atual gestão.

Destaca-se que a maioria dos produtos são importados, sendo a China o principal fabricante (61,28\% dos produtos) com o total de registros de agrotóxicos aprovados maior do que a soma de todos os demais países, seguida pelo Brasil (13,23\%) e EUA (5,51\%). Dentre os ingredientes ativos (IA) ou misturas de IA que estão na composição dos novos produtos - técnicos ou formulados - aprovados no período, pelo menos $25 \%$ são proibidos nos países exportadores. Observou-se que produtos fabricados na China (35), Índia (11), Suíça (2), França (3) e Alemanha (1) foram aprovados no Brasil, apesar de não terem aprovação nestes países. A base de dados dos IA aprovados nos EUA não foi acessada e, portanto, esses números não incluem produtos fabricados neste país.

Em relação à toxicidade aguda para humanos, que trata dos efeitos que podem surgir nas primeiras horas após uma exposição, em 23,87\% dos Atos publicados pelo Mapa essa informação não estava explicitada. Considerando os que traziam essa informação ( $n=759)$, a maioria $(40,97 \%)$ é classificada como pouco tóxico ou improvável de causar dano agudo (grupos IV e V), e 8,43\% das substâncias são categorizadas como não classificadas quanto à toxicidade aguda. Isso significa que, segundo as mudanças nas regulamentações implementadas em

\footnotetext{
${ }^{5}$ Diversos autores defendem que o impeachment da presidenta eleita Dilma Rousseff constitui um marco da ruptura democrática brasileira, estreitamente relacionado com os atuais retrocessos em curso no Brasil. Esta tese sustenta-se, dentre outros fatores, na premissa de não houve situação típica que configurasse crime de responsabilidade para o afastamento, ou seja, as condições legais e constitucionais para que o seu uso se verificasse não foram satisfeitas (Kozicki \& Chueiri, 2019; Mustafá et al., 2018; Santos \& Szwako, 2016).
} 
2019 (Anvisa, 2019a), o rótulo desses produtos (49,40\% do total) não exibe o pictograma da caveira com duas tíbias cruzadas, símbolo universal para indicar substâncias perigosas. Apesar disso, essas substâncias podem estar associadas a agravos crônicos à saúde, como cânceres, danos ao material genético, malformações genéticas, danos ao aparelho reprodutor, malformação em bebês, desregulação hormonal e outros problemas graves, indicando que as mudanças normativas ocultam o risco para as populações expostas. Ainda, $14,88 \%$ dos produtos foram classificados como extremamente tóxicos (grupo I) e $8,69 \%$ como altamente tóxicos (grupo II), apresentando faixa vermelha no rótulo, que sinaliza maior nível de alerta, indicando substâncias com elevada toxicidade, que podem causar morte após a exposição a níveis de dose muito baixos. É importante reforçar que a classificação toxicológica não considera os efeitos crônicos, que surgem tardiamente.

Considerando o potencial de periculosidade ambiental, que identifica a capacidade de causar impactos ambientais negativos como a contaminação de espécies, recursos hídricos e do solo, 48,14\% dos agrotóxicos liberados são classificados como muito perigosos para o ambiente (classe II) e 34,10\% como produtos perigosos ao ambiente (classe III) e 3,12\% como altamente perigosos para o ambiente (classe I), indicando que $85,36 \%$ dos produtos autorizados representam um grau de ameaça importante para o ambiente. Somente $14,64 \%$ dos agentes foram categorizados como pouco perigosos. Esses dados apontam que a liberação acelerada de uma grande quantidade de produtos de elevada periculosidade ambiental representa um problema para diferentes espécies e compromete a qualidade das águas e dos solos. Esses agentes podem permanecer no ambiente ou no organismo de animais expostos por longos períodos, a depender das propriedades dos agrotóxicos e das características do ambiente. Pode haver perda de biodiversidade, adoecimento de diferentes espécies e contaminação ambiental e exposição humana mediante o consumo de água e de alimentos de origem animal e vegetal contendo resíduos de agrotóxicos, ou via exposição ao solo, ao ar e à água contaminados.

\subsection{Reavaliação toxicológica de agrotóxicos}

A reavaliação do registro de agrotóxico está prevista na legislação brasileira (Brasil, 1989; 2002) e consiste em um procedimento administrativo realizado quando surgirem indícios da ocorrência de riscos que desaconselhem o uso de produtos registrados ou quando o país for alertado nesse sentido por organizações internacionais responsáveis pela saúde, alimentação ou ambiente, das quais o Brasil seja membro integrante ou signatário de acordos. Os agrotóxicos, seus componentes e afins que apresentarem indícios de redução de sua eficiência agronômica, alteração dos riscos à saúde humana ou ao ambiente poderão ser reavaliados em qualquer tempo e ter seus registros mantidos, alterados, suspensos ou cancelados. Se a conclusão do processo apontar que o produto está associado a pelo menos um dos critérios indicativos de proibição de registro, o ingrediente ativo é banido do país.

Segundo a legislação em vigor, o produto será banido: (i) se houver evidências de carcinogenicidade, teratogenicidade, mutagenicidade, desregulação hormonal e danos ao aparelho reprodutor; (ii) se o país não dispor de métodos para desativação de seus componentes de modo a impedir que os seus 
resíduos remanescentes provoquem risco ao meio ambiente e à saúde pública; (iii) se não houver antídoto ou tratamento eficaz no país; (iv) se o agrotóxico se revelar mais perigoso para o homem do que os testes de laboratório tenham podido demonstrar; ou (v) cujas características causem danos ao meio ambiente (Brasil, 1989; 2002).

No caso de suspeita de efeitos adversos à saúde, o produto é avaliado pela Agência Nacional de Vigilância Sanitária (Anvisa), órgão responsável pela análise dos impactos sobre a saúde humana. Entre 2019 e 2020, a Anvisa concluiu a reavaliação de cinco ingredientes ativos de agrotóxicos, incluindo os dois ativos mais utilizados no país: glifosato e 2,4-D, além da abamectina, tiram e paraquate. À exceção do 2,4-D, todos os processos de reavaliação haviam sido iniciados há mais de uma década, demonstrando a morosidade do processo, que frequentemente é fruto de judicialização por parte dos interessados em seu registro. Frequentemente, o setor regulado tenta se imiscuir junto ao órgão regulador, fazendo pressão para assegurar suas vantagens econômicas a partir da interferência no processo de regulação. Para driblar as leis sanitárias, as indústrias colocam em dúvida descobertas científicas, interferindo negativamente no processo regulatório (Michaels, 2008) e arrastando o processo de reavaliação de registro por vários anos.

No caso dos agrotóxicos em questão, observa-se claramente a interferência do setor regulado no processo. Além da judicialização, em todos os casos as indústrias instituíram "Forças Tarefa" (Task Forces), que são grupos formados pelas empresas registrantes para atuarem junto às agências reguladoras nos processos regulatórios de seus produtos (Friedrich et al., 2021). As Forças Tarefa interferem no processo de regulação estatal de diversas manei- ras, destacando-se a produção de informações para atestar a segurança de seus produtos; a desqualificação de estudos, pesquisadores e instituições que produzam dados que evidenciem danos associados aos mesmos; e a articulação e pressões para interferir diretamente nas decisões do poder público, particularmente no legislativo.

Durante o período considerado na presente análise, os casos dos agrotóxicos que tiveram seu registro reavaliado demonstram claramente este processo de interferência, como apresentado a seguir.

\section{- Glifosato}

No caso do glifosato, a atuação da Força Tarefa Glifosato foi determinante para a tomada de decisão da Anvisa, que manteve o registro do produto. A Agência concluiu oficialmente que o glifosato não apresenta características mutagênicas, teratogênicas e carcinogênicas, não é desregulador endócrino e não é tóxico para a reprodução (Anvisa, 2019a).

No entanto, existem evidências contundentes que atestam a associação entre o glifosato e diversos danos à saúde, inclusive aqueles considerados proibitivos para fins de registro (Abrasco, 2019). Ressalta-se a classificação do glifosato como provável cancerígeno humano (grupo $2 \mathrm{~A}$ ) pela Agência Internacional de Pesquisa em Câncer (Iarc) (Iarc, 2015).

A associação do glifosato com o câncer, especialmente do tipo Linfoma Não-Hodgkin (LNH), foi reconhecida pela justiça norte-americana, que se pautou nas evidências provenientes de diversos estudos científicos, resultando na perda de processos bilionários pela Monsanto, sua maior produtora. Na ação judicial, foi revelado que esta corporação transnacional não avaliou de maneira adequada a 
real toxicidade de seus produtos; ocultou estudos com resultados desfavoráveis à manutenção destes; contratou "escritores fantasma"; interferiu no processo de revisão pelos pares em artigos submetidos à periódicos científicos; influenciou a criação de um site acadêmico de fachada para defender os produtos da Monsanto; e perseguiu ativa e sistemicamente instituições e pesquisadores independentes que publicaram estudos que ameaçavam seus interesses (McHenry, 2018; Krimsky \& Gilliam, 2018).

\section{- 2,4-D}

Assim como no caso do glifosato, a Força Tarefa 2,4-D foi decisiva para manter o registro desse ingrediente ativo. A Anvisa concluiu que não existem efeitos proibitivos de registro associados ao 2,4-D segundo a lei brasileira, baseando-se no parecer elaborado pela Força Tarefa, que desqualificou sistematicamente as evidências que atestavam danos à saúde humana associados a este herbicida (Anvisa 2015a).

O 2,4-D é possivelmente cancerígeno (grupo 2B) (Agência Internacional de Pesquisa em Câncer - Iarc, 2017) e está relacionado ao surgimento de LNH, sarcomas (Garabant \& Philbert, 2002; Miligi et al., 2006), câncer de cólon e leucemia (Yi et al., 2013) e genotoxicidade (Garaj-Vrhovac \& Zeljezic, 2002). Também pode alterar o desempenho sexual e a fertilidade, exercer efeitos tóxicos no feto e em lactentes e interferir no desenvolvimento motor, comportamental, intelectual, reprodutivo, hormonal ou imunológico, provocando aborto ou morte nos primeiros meses de vida (Friedrich, 2014). Outro problema associado ao 2,4-D é a possibilidade de serem produzidas, de forma não intencional, dioxinas, classificadas como poluentes orgânicos persistentes, reconhecidas por causarem câncer e outros problemas (Sears et al., 2006).

\section{- Tiram}

Quanto ao Tiram, o processo de reavaliação também foi fortemente influenciado pela Força Tarefa. Assim como nos casos do glifosato e 2,4-D, o registro do produto foi mantido, a despeito das evidências de danos graves e potencialmente irreversíveis para a saúde humana. Mais grave ainda é o fato de o Parecer Técnico de Reavaliação não ter apresentado estudos de toxicidade aguda, subaguda e crônica, necessários para a avaliação dos potenciais danos à saúde e adequação aos critérios de proibição de registro. No documento da Anvisa, ficou evidente a interferência da Força Tarefa para desqualificar e desconsiderar estudos independentes do processo de reavaliação. Existem evidências da relação do Tiram com efeitos sobre a reprodução e função hormonal, citotoxicidade e estresse oxidativo em eritrócitos humanos (Salam et al., 2020).

$\mathrm{Na}$ conclusão do processo, a Anvisa publicou um parecer incompleto, sem apresentar estudos de toxicocinética, toxicidade aguda, subcrônica e crônica. Apesar da ausência de informações essenciais para o processo de reavaliação toxicológica, a Agência declarou que, quanto à toxicidade reprodutiva, "devido ao pouco tempo concedido judicialmente, não foi possível analisar todos os estudos disponíveis" (Anvisa, 2015b, p. 29).

Entretanto, não é tecnicamente recomendável indicar a "manutenção de registro de agrotóxicos

\footnotetext{
${ }^{6}$ Pesquisadores renomados que, embora não tenham participado diretamente dos estudos financiados pela indústria, assinaram a autoria destes com o propósito de conferir credibilidade às publicações.
} 
sem alterações" sem que aspectos importantes sejam avaliados, principalmente porque são considerados cruciais para a proteção da saúde da população dever maior de uma instituição como a Anvisa. $\mathrm{O}$ parecer demonstra ainda que a maior parte dos estudos publicados por grupos independentes foi desconsiderada no processo, revelando que a decisão se baseou, fundamentalmente, em estudos fechados e apresentados pela Força Tarefa das indústrias (Friedrich et al., 2019).

\section{- Paraquate}

O paraquate foi o único produto cuja conclusão da reavaliação, em setembro de 2020, resultou em seu banimento. Na verdade, a Anvisa ratificou a conclusão pelo banimento emitida pela própria Agência em 2017 (Anvisa, 2017), após muita pressão da sociedade e de entidades de pesquisa e ensino. Embora a decisão pelo banimento tenha sido tomada em setembro de 2020, a medida permitiu o uso dos estoques do produto até 2021, atendendo ao pleito de setores do agronegócio (Anvisa, 2020a). Segundo a própria Procuradoria Jurídica da Anvisa, não foram "apresentados os motivos e razões pela gestão dessa Anvisa que justifiquem e fundamentem, com suporte técnico, científico, sanitário a viabilidade e necessidade da alteração do marco regulatório" (Anvisa, 2020b).

Contudo o lobby do setor regulado pressionou, especialmente por meio da Força Tarefa Paraquate, para que o produto não tivesse seu uso proibido na data programada. A Força Tarefa conduziu estudos de genotoxicidade e "encomendou" um estudo - que constituiria a peça central para reverter sua proibi- ção - a um pesquisador de uma tradicional Universidade brasileira. Após denúncia dessa situação ${ }^{7}, 0$ Departamento de Saúde Coletiva da Faculdade de Ciências Médicas da Unicamp posicionou-se "enfaticamente a favor do banimento" do paraquate, reconhecendo a existência de "conflito de interesse" no estudo e considerando a tentativa de suspensão temporária do banimento do produto "extemporânea, vil e oportunista” (Unicamp, 2020).

Além de elevada toxicidade aguda, o paraquate apresenta potencial genotóxico (Garaj-Vrhovac \& Zeljezic, 2002), está associado à ocorrência de cânceres (Andreotti et al., 2020; Park et al., 2009) e desordens neurodegenerativas como parkinsonismo (Tangamornsuksan et al., 2019). A decisão de manter o seu uso permite que a população continue se expondo a um produto considerado pela própria Anvisa como causador de graves danos à saúde (Anvisa, 2017).

\section{- Abamectina}

Em dezembro de 2020, a Anvisa concluiu pela manutenção do registro do ingrediente ativo abamectina. Repetindo o modus operandi dos outros processos de reavaliação concluídos nos últimos anos, a atuação da Força Tarefa instituída pelas empresas foi decisiva para o posicionamento da Agência. A decisão se deu a despeito da Fundação Oswaldo Cruz (Fiocruz) - instituição do Ministério da Saúde e um dos mais importantes e respeitados centros de pesquisa da América Latina - ter apontado em Nota Técnica preocupações quanto à elevada toxicidade para humanos e animais e quanto à potencial relação da abamectina com casos

\footnotetext{
${ }^{7}$ Em reportagem intitulada "Lobby usa pesquisa não concluída para pressionar Anvisa sobre agrotóxico proibido", de autoria de Ana Aranha e Hélen Freitas, publicada pela Repórter Brasil, em 17 de julho de 2020. Disponível em: <https://reporterbrasil.org.br/2020/07/lobby-usa-pesquisa-nao-concluida-para-pressionar-anvisa-sobre-agrotoxico-proibido/>.
} 
de toxicidade para os sistemas nervoso, endócrino e reprodutivo, além de afetar o desenvolvimento (Anvisa, 2015c).

A própria Anvisa apontou a abamectina como suspeita de causar toxicidade reprodutiva em seres humanos e suspeitas adicionais de causar efeitos adversos na lactação. A Agência recomendou ainda que, nas bulas, fossem incluídos alertas de que o produto pode prejudicar o feto, causando malformações congênitas, e que pode ser nocivo às crianças alimentadas com leite materno (Anvisa, 2020c). A legislação brasileira, contudo, é muito clara quanto à proibição de produtos associados à malformação fetal (Brasil, 1989; 2002), não cabendo advertência quando a medida prevista nesses casos é o banimento.

Além de ignorar estudos críticos, outra estratégia que merece ser mencionada diz respeito aos constrangimentos à autonomia e à liberdade acadêmica de pesquisadores que produzem evidências científicas demonstrando a ocorrência de danos ambientais e à saúde decorrentes da exposição aos agrotóxicos. Frequentemente, as empresas detentoras do registro têm perseguido cientistas independentes que divulguem evidências contrárias aos seus interesses. Outras ações, como a instauração de processos judiciais, campanhas públicas de ameaça, interpelações judiciais, interditos proibitórios, demandas de descredenciamento e outras formas de pressão (incluindo a ameaça direta à vida de pesquisadores que evidenciam os impactos dos agrotóxicos), vêm sendo reportadas (Acselrad, 2014; Bombardi, 2021; Fagan et al.,
2015; McHenry, 2018). Importa destacar que, segundo Sanctis \& Mendes (2020, n.p.), o "projeto de cerco ao conhecimento científico não começou com a posse do presidente Bolsonaro, mas a partir dali se intensificou, de modo notável, como política de governo".

Os interesses econômicos das indústrias agroquímicas atuam como verdadeiras forças motrizes sobre os órgãos reguladores, a despeito do reconhecimento de que os agrotóxicos comprometem a saúde das populações expostas e o potencial de resiliência dos sistemas de suporte à vida na biosfera. Como resultado, vem se impondo ao longo do tempo a subordinação do Estado aos interesses privados e de mercado, com o consequente enfraquecimento do interesse público (Friedrich et al., 2019).

\subsection{Mudanças nos procedimentos de avaliação de toxicidade, risco e comunicação de risco}

O cenário pós-impeachment abriu oportunidades para a implementação de pautas antigas inscritas na agenda do agronegócio brasileiro. A principal delas trata da simplificação de regras e normas para registro, avaliação e uso de agrotóxicos no Brasil, materializadas no Projeto de Lei (PL) $n^{\circ} 6.299 / 2002^{8}$. Em 2018, o projeto de autoria de Blairo Maggi - um grande ruralista brasileiro e um dos maiores produtores individuais de soja do mundo -, tramitou na Câmara dos Deputados. O PL teve sua recomendação aprovada pelo relator

\footnotetext{
${ }^{8}$ O PL no 6.299/2002, conhecido como "Pacote do Veneno", constitui um exemplo emblemático da aceleração da tramitação deste tipo de pauta no Congresso Nacional. Este projeto foi conformado a partir do apensamento de dezenas PLs elaborados entre 2000 e 2017 e que têm em comum o desmonte do sistema normativo regulatório de agrotóxicos no Brasil.
} 
do projeto, o deputado Luiz Nishimori, que além de presidente de empresas que comercializavam agrotóxicos e pertencem a membros de sua família, integra a Frente Parlamentar da Agropecuária (FPA), financiada pelo setor privado e interessada direta na aprovação do projeto.

Em oposição ao PL n ${ }^{\circ} 6.299 / 2002$, forças progressistas pressionaram para que também tramitasse na Câmara o PLn ${ }^{\circ}$ 6.670/2016, que institui a Política Nacional de Redução de Agrotóxicos (Pnara). A Pnara foi uma demanda da sociedade civil, e propõe a ampliação de investimentos públicos para que alternativas técnicas aos agrotóxicos sejam disseminadas e/ou desenvolvidas, contribuindo para atender às necessidades de aumento da produção de alimentos saudáveis e diversificados, e que promovam a saúde coletiva e protejam o ambiente (Abrasco \& ABA, 2018).

Frente às dificuldades para aprovação do $P L n^{\circ}$ 6.299/2002, devido às forças contrárias e à extensa pauta de flexibilização de outras normas-sobretudo as reformas trabalhistas e tributárias - o governo decidiu realizar as mudanças previstas no PL sem tramitar pelo legislativo. Assim, as mudanças estão sendo implementadas via executivo, por meio de normas infralegais. As principais medidas efetivadas no âmbito da Anvisa, durante os primeiros dois anos de governo, foram as Resoluções da Diretoria Colegiada (RDC) no 294, 295 e 296/2019 (Anvisa, 2019a; 2019b; 2019c), que instituíram:

- Mudanças na classificação toxicológica dos agrotóxicos

Os efeitos agudos - que surgem poucas horas após a exposição a um agrotóxico - sofreram alteração na classificação a partir da RDC nº 294. Anteriormente, os efeitos eram classificados em quatro grupos (extremamente, altamente, moderadamente e pouco tóxico), de acordo com a gravidade de efeitos agudos decorrentes da exposição. A nova classificação anunciada pela Anvisa estabelece que os produtos devem ser classificados como: Categoria 1: Produto Extremamente Tóxico - faixa vermelha; Categoria 2: Produto Altamente Tóxico - faixa vermelha; Categoria 3: Produto Moderadamente Tóxico - faixa amarela; Categoria 4: Produto Pouco Tóxico - faixa azul; Categoria 5: Produto Improvável de Causar Dano Agudo - faixa azul; e Produto Não Classificado - faixa verde.

Além da inclusão de novas categorias, os estudos passaram a ser analisados considerando apenas o risco imediato de morte, e os estudos toxicológicos de irritação dérmica e ocular deixaram de ser utilizados para fins de classificação toxicológica. Assim, ainda que o agrotóxico possa causar danos agudos graves como corrosão ocular e cegueira, esses desfechos não vão interferir na classificação da toxicidade (Gurgel \& Friedrich, 2020).

- Não definição dos estudos obrigatórios a serem apresentados para fins de registro

ARDC n² 294 não cita os estudos que devem ser apresentados pelas empresas no momento do registro ou da revisão de registro, limitando-se a citar apenas aspectos gerais dos estudos. Diferentemente, a portaria anterior, substituída por esta normativa, definia os obrigatórios estudos, como os de teratogenicidade e de carcinogenicidade em pelo menos duas espécies de animais de laboratório e estudos de mutação no material genético (Gurgel \& Friedrich, 2020).

A não definição dos estudos a serem apresentados cria uma lacuna que pode isentar as empresas de apresentar os dados necessários para uma adequada avaliação de seus potenciais danos à saúde. 
- Alteração nos critérios para avaliação do risco dietético

Outro importante retrocesso foi a não definição dos estudos necessários para o cálculo das doses de ingestão, necessários para avaliação do risco dietético decorrente da exposição humana a resíduos de agrotóxicos, disposto na RDC n ${ }^{\circ} 295$ (Anvisa, 2019b). Ao não especificar os estudos necessários para o cálculo das doses que teoricamente uma pessoa poderia se expor sem manifestar efeitos agudos e crônicos, os valores definidos podem não refletir o potencial de danos relacionados às substâncias avaliadas (Gurgel \& Friedrich, 2020).

Embora esse cálculo apresente diversas limitações - que variam desde a consideração da existência de uma "dose aceitável de ingestão" (científica e eticamente inaceitável frente à exposição a agentes nocivos), à negligência dos efeitos aditivos, sinérgicos e a exposição por múltiplas vias -, sua definição deve minimamente partir de estudos definidos pela Agência Reguladora, e não estar a critério do setor regulado.

- Mudança na estratégia de comunicação de risco

Com a justificativa de adequar-se ao Sistema Globalmente Harmonizado de Classificação e Rotulagem de Produtos Químicos (GHS), a Anvisa resolveu remover o pictograma do crânio com duas tíbias cruzadas, tradicionalmente utilizado para identificar "veneno" dos rótulos de produtos das classes 4 e 5 . Considerando as condições de uso de agrotóxicos no país, onde um número significativo de trabalhadores que utilizam esses produtos possui baixo grau de escolaridade e dificuldade de ler e interpretar adequadamente textos simples, a retirada do pictograma oculta uma informação essencial para a compreensão do nível de ameaça à saúde. Isso demonstra que, embora toda a população esteja sob risco, a maior carga dos danos se concentra nos grupos populacionais mais vulnerabilizados, como trabalhadores, população do campo, indígenas, quilombolas, ribeirinhos e outros (Gurgel \& Friedrich, 2020).

\subsection{Liberação tácita (automática) de agrotóxicos}

A portaria $\mathrm{n}^{\circ} 43$, de fevereiro de 2020 (Mapa, 2020a), estabeleceu um prazo máximo de 60 dias para deferir ou indeferir os atos públicos de liberação de agrotóxicos sob responsabilidade do Mapa. Se o pleito de registro não for analisado dentro deste prazo, o agrotóxico é liberado sem passar por qualquer procedimento de análise do órgão. A medida coloca o Mapa como ente máximo de fiscalização e regulação de agrotóxicos no Brasil, ao mesmo tempo em que fragiliza o processo regulatório. Ao não conferir estrutura e tempos adequados para a avaliação dos pleitos, transforma o órgão em um mero chancelador, diminuindo seu papel de indutor e fomentador do planejamento agrícola nacional (Souza et al., 2020). Contudo o STF impugnou a portaria, impedindo que a liberação indiscriminada fosse instituída mediante ato normativo.

\subsection{Flexibilização das regras de pulverização aérea}

No Brasil, as normativas que regulam a pulverização aérea de agrotóxicos determinam uma distância mínima de segurança que proíbe a operação de aeronaves agrícolas a menos 500 metros 
da população (povoações, cidades, vilas, bairros) e 250 metros de mananciais de água. Mas essa distância não é suficiente para evitar a dispersão dos agrotóxicos para além "dos cultivos alvo", ocorrendo tanto casos de deriva acidental, quanto casos de deriva técnica (dispersão que ocorre mesmo quando todas as medidas de segurança previstas nas normativas vigentes são adotadas). A deriva indica que a pulverização aérea é um método comprovadamente de baixa eficácia, uma vez que uma parcela significativa dos agrotóxicos aplicados não chega até as plantas. Estudos realizados no Brasil e no mundo apontam perdas variando entre $34,5 \%$ e $82 \%$ (Fiocruz, 2019b).

Em abril de 2020, o Mapa publicou uma normativa reduzindo a distância de segurança mínima de 500 para 250 metros para a pulverização aérea de fungicidas agrícolas e de óleo mineral na cultura da banana (Mapa, 2020b). A mudança ocorreu sem qualquer justificativa científica que indicasse a segurança dessa redução da distância de pulverização.

Existe a suspeita de que essa mudança tenha sido motivada para beneficiar produtores rurais do agronegócio da banana no Vale do Ribeira, em São Paulo, um importante reduto eleitoral dos Bolsonaro e local de residência de parte de sua família. Já para as dezenas de comunidades quilombolas que residem na área, a medida implica em aumento das vulnerabilidades. Por se tratar de uma região de preservação ambiental de Mata Atlântica, a medida ameaça também o bioma (Souza et al., 2020).

Na União Europeia, “os Estados-Membros asseguram que seja proibida a pulverização aérea de agrotóxicos", considerando-a "susceptível de prejudicar significativamente a saúde humana e o ambiente, nomeadamente devido ao arrastamento da pulverização" (Parlamento Europeu, 2009).
A manutenção dessa prática está associada a danos à saúde e ao ambiente, amplamente denunciados em estudos científicos e documentos técnicos produzidos por entidades e instituições de Saúde como a Abrasco e Fiocruz (Carneiro et al., 2015; Abrasco, 2016; Gurgel et al., 2015; 2018).

\subsection{Liberação do uso de agrotóxicos proibidos no Brasil em casos de emergência fitossanitária}

No Brasil, somente podem ser utilizados os agrotóxicos que foram previamente aprovados no processo de registro, que envolve análise toxicológica, ambiental e de eficiência agronômica, realizados respectivamente pela Anvisa, pelo Instituto Brasileiro do Meio Ambiente e dos Recursos Naturais Renováveis e pelo Ministério da Agricultura, Pecuária e Abastecimento (Brasil, 1989; 2002).

Contudo desde 2013, em casos de "emergência fitossanitária ou zoossanitária", a autoridade agropecuária pode importar e conceder autorização emergencial temporária para produção, distribuição, comercialização e uso de agrotóxicos e afins com uso não autorizado no país. Esta liberação ocorre sem as exigências de apresentação de potenciais danos à saúde e de impactos ao ambiente, representando riscos para a saúde pública. Trata-se de uma medida que integra o processo de flexibilização da legislação de agrotóxicos (Gurgel et al., 2017), intensificado após 2016.

Tendo como prerrogativa essa previsão legal, em junho de 2020, o Mapa declarou "estado de emergência fitossanitária" no Rio Grande do Sul e em Santa Catarina devido ao risco de surto nas áreas produtoras dos dois estados, em decorrência 
da aproximação de uma nuvem de gafanhotos (Schistocerca cancellata), vinda da Argentina (Mapa, 2020c). Embora a medida anteceda o governo atual, a decisão é vista com preocupação, pois representa, em um contexto de liberação acelerada de novos agrotóxicos no Brasil, a possibilidade de autorização do uso de venenos associados a danos graves para a saúde humana e para o ambiente.

\subsection{Revisão da Portaria de Potabilidade da Água}

Em 2020, o Ministério da Saúde divulgou a minuta da nova redação da portaria de potabilidade de água para consumo humano, que inclui a definição de parâmetros para monitoramento da presença de agrotóxicos em água (MS, 2020). O documento divulgado, embora traga alguns avanços em comparação com a normativa anterior, apresenta importantes limitações, que comprometem a segurança das populações expostas (Rosa et al., 2020). Em maio de 2021, a portaria ${ }^{0} 888$ foi finalmente publicada, consolidando as modificações propostas (Brasil, 2021).

A portaria prevê o monitoramento de apenas 40 parâmetros de agrotóxicos, embora existam mais de 500 ingredientes ativos com uso autorizado no Brasil. Mais grave ainda é o fato de que o 2,4-D, um dos agrotóxicos mais consumidos no país, não figura entre os monitorados, embora existam evidências da sua associação a desfechos extremamente graves.

Outro problema é que o documento estabelece o valor máximo permitido (VMP) de cada substância por amostra, negligenciando a possibilidade de uma mesma amostra apresentar mais de um contaminante, e que estes podem agir sinergicamente.
O efeito cumulativo não é considerado e não há definição de limite ou concentração de substâncias por amostra. É necessário, ainda, analisar de forma criteriosa o cálculo de VMP, compreendendo que, mesmo que as substâncias identificadas estejam situadas abaixo do limite máximo definido, a simples presença de um agrotóxico já indica a contaminação da água, uma vez que a concentração esperada desses agentes nesse meio é zero. Para muitos dos problemas associados à exposição aos agrotóxicos, qualquer dose diferente de zero é suficiente para causar um dano, o que implica afirmar que não existe uma dose de exposição considerada segura (Rosa et al., 2020).

Também não foi considerado o diferencial de risco segundo o grupo exposto. Por exemplo, crianças são mais vulneráveis, pois apresentam metade do peso corpóreo e o cálculo do VMP médio não faz essa distinção, definindo níveis de exposição semelhantes para crianças e adultos. É necessário que os valores máximos permitidos sejam mais protetivos para crianças, pois nesta etapa do desenvolvimento os danos podem ser mais graves e mesmo potencialmente irreversíveis (Rosa et al., 2020).

A portaria também não define o que fazer em caso de não conformidade da amostra, particularmente no que diz respeito às ações a serem desenvolvidas pelas concessionárias e pela vigilância em saúde (Rosa et al., 2020).

\subsection{Autorização da queima de resíduos de agrotóxicos em fornos de cimenteiras}

Em outubro de 2020, o Conselho Nacional do Meio Ambiente (Conama) licenciou a atividade de coprocessamento de resíduos em fornos rotativos 
de produção de clínquer, incluindo agrotóxicos (Conama, 2020). O documento autoriza inclusive a queima de agrotóxicos organoclorados, banidos praticamente no mundo inteiro devido à sua elevada capacidade de bioacumulação em organismos vivos e de permanência no ambiente por longos períodos, além de muitos destes estarem associados a problemas como câncer e desregulação hormonal (Iarc, 2020). A resolução estabelece um limite máximo para esses compostos, ignorando que para carcinógenos genotóxicos e desreguladores endócrinos (como é o caso de vários organoclorados listados no documento), não há limite seguro de exposição (Friedrich et al., 2021).

\section{4. À guisa de conclusão: flexibilização das normativas e a racionalidade necropolítica neoliberal como reflexos da lógica de biopoder e da força motriz do racismo ambiental}

O período de 2019 a 2020 caracterizou-se por uma intensificação dos desmontes nas normativas que regulam o registro e uso de agrotóxicos no Brasil, com reflexos negativos para o ambiente e a saúde humana. A liberação recorde de 997 agrotóxicos em apenas dois anos, os retrocessos na regulação impostos diretamente via executivo e a interferência política do setor regulado junto à Anvisa evidenciam como as práticas de biopoder têm ditado os rumos das medidas voltadas à proteção da saúde e da vida. Estas medidas culminaram, por exemplo, na manutenção de substâncias associadas a danos extremamente graves e potencialmente irreversíveis (como o glifosato, o 2,4-D, a abamectina e o tiram) ou resultaram em um longo processo de phase-out de retirada de produtos (como o paraquate) do mercado, prolongando a exposição humana a estes agentes tóxicos.

Observa-se uma associação entre o agronegócio e a violação de direitos humanos fundamentais, como o direito à saúde, ao meio ambiente equilibrado, à água e ao direito humano à alimentação adequada e à soberania alimentar (Souza et al., 2020).

A compreensão da política do Estado liberal adotada pelo governo brasileiro e de sua influência e capacidade de determinar a adoção de medidas que flexibilizam o uso de agrotóxicos, a despeito de seus impactos para a saúde e para o ambiente, pode ser entendida a partir da ótica do biopoder tematizada nas reflexões de Michel Foucault. A interferência das empresas no Estado representa uma estratégia fundamental para a consolidação de práticas de biopoder voltadas para atender aos interesses do capital financeiro, manipulando a própria ciência e as leis para a adoção de medidas que, não raro, resultam em danos à saúde e ao ambiente (Friedrich et al., 2021). Diferente do poder soberano de "fazer morrer e deixar viver", o biopoder trouxe o direito de "fazer viver e deixar morrer" (Foucault, 1999).

É indispensável ao capitalismo o controle dos corpos e sua inserção na ordem econômica, extraindo suas forças, fazendo-o crescer em utilidade e docilidade para integrá-lo aos sistemas de controle e econômicos, em uma estratégia que obtém sua subjugação e o controle das populações (Foucault, 1979). Contudo o sistema não é igualitário: há os que subjugam e os que são subjugados. Assim, operam também fatores de segregação e de hierarquização social, garantindo relações de dominação. O poder que reprime, legitima e viabiliza a gestão dos corpos, prevê e define o que pode colocar a vida em risco. Mais 
importante ainda, define a vida de quem pode ser posta em risco. Assim, condições de precariedade e vulnerabilidade são condições produzidas pela biopolítica (Foucault, 2007). Essa distinção entre os cidadãos estabelece sobre quem devem recair os custos do modelo de desenvolvimento no modo capitalista de produção. Esse racismo é funcional ao capital, constituindo um meio de definir o que deve viver e o que deve morrer, fragmentando a sociedade (Foucault, 1999).

$\mathrm{O}$ racismo extrapola as questões raciais e étnicas, envolvendo injustiças, preconceitos e desigualdades. Em sua dimensão ambiental, aponta que os impactos decorrentes do crescimento econômico acometem de modo particular determinadas populações e grupos em maior situação de vulnerabilidade. O racismo ambiental parte do pressuposto de que a injustiça social e a degradação ambiental têm a mesma raiz, onde o modo de distribuição desigual de poder sobre os recursos naturais transfere os custos ambientais do desenvolvimento para os mais despossuídos, que se expõem de forma mais intensa a situações de risco (Acselrad, 2010). Assim, a maior carga dos danos ambientais gerados por este modelo de desenvolvimento recai nas populações de baixa renda, nos grupos raciais discriminados, nos povos e comunidades tradicionais, nos bairros operários, nas populações marginalizadas e vulneráveis (Acselrad et al., 2004).

Segundo Foucault, o racismo é acima de tudo uma tecnologia destinada a permitir o exercício do biopoder, "este velho direito soberano de matar", tendo como função regular a distribuição da morte e tornar possíveis as funções assassinas do Estado, sendo "a condição para a aceitabilidade do fazer morrer” (Mbembe, 2018, p. 18). A expressão máxima da soberania reside, em grande medida, no poder e na capacidade de ditar quem pode viver e quem deve morrer. A racionalidade necropolítica neoliberal presente na organização da sociedade e do Estado reflete o paradigma da divisão entre segmentos sociais, que regulamenta - e regulariza - o poder de gestão da vida, e dita quem pode viver e quem deve morrer para garantir o funcionamento do capitalismo (Agostini \& Castro, 2019). As políticas de morte são engendradas tanto pela ausência do Estado como por sua atuação enquanto poder regulador da manutenção da vida e da morte, materializadas na necropolítica (Mbembe, 2018).

A pandemia de Covid-19 e sua relação com o agronegócio traz elementos importantes para a compreensão da necropolítica. Por exemplo, ao passo que as exportações do agronegócio devem bater recorde e superar a barreira dos US\$ 100 bilhões pela segunda vez na história, auferindo grandes lucros aos ruralistas produtores de commodities (Batista, 2021), os agricultores familiares do Brasil enfrentam uma crise sem precedentes e não conseguem escoar suas mercadorias. Ainda, grande parte da população brasileira viu a renda familiar despencar e não consegue acessar itens de primeira necessidade (Gurgel et al., 2020). Assim, a crise sanitária aumenta os rendimentos de um pequeno grupo privilegiado, levando alguns autores a afirmar que "a pandemia poderá ter efeitos benéficos e aumentar a oferta da produção e a inserção internacional do agronegócio do Brasil" (Schneider et al., 2020, p. 187). Em contrapartida, o número de pessoas que sofrem de fome crônica pode aumentar drasticamente, resultando no incremento da insegurança alimentar e nutricional devido à incapacidade do projeto ultraneoliberal do governo de responder adequadamente à crise (Gurgel et al., 2020). 
Considerando o impacto dos agrotóxicos para a sociedade, fica, portanto, evidente o racismo ambiental e o poder necropolítico, que determinam uma maior carga de nocividades às populações em maior situação de vulnerabilidade. As medidas de flexibilização da legislação, que reduzem ou mesmo eliminam as medidas de proteção social, à saúde e ao ambiente, aumentam as situações de perigo e risco ao intensificar a exposição aos agrotóxicos e fragilizar os mecanismos de proteção individual e coletiva.

Uma vez que os Estados foram tomados pelos interesses das corporações capitalistas, cabe à sociedade resistir e lutar pela transformação das estruturas de poder vigentes (Marques, 2018).

\section{Referências}

Abrasco - Associação Brasileira de Saúde Coletiva. Nota contra pulverização aérea de inseticidas para controle de vetores. Rio de Janeiro: Abrasco, 2016. Disponível em: $<$ https://tinyurl.com/y6lkhvy4>. Acesso em: set. 2020.

Abrasco - Associação Brasileira de Saúde Coletiva. Parecer Técnico sobre processo de reavaliação do ingrediente ativo de agrotóxico glifosato utilizado na agricultura e como produto domissanitário. Rio de Janeiro: Abrasco, 2019. Disponível em: <https://tinyurl.com/y64pfjvw>. Acesso em: out. 2020.

Abrasco - Associação Brasileira de Saúde Coletiva; ABA Associação Brasileira de Agroecologia. Dossiê científico e técnico contra o Projeto de Lei do Veneno (PL 6.299/2002) e a favor do Projeto de Lei que institui a Política Nacional de Redução de Agrotóxicos (Pnara). Friedrich, K.; Souza, M. M. O.; Carneiro, F. F. Rio de Janeiro: Abrasco/ABA, 2018. Disponível em: <https://tinyurl.com/y5c92ck8>. Acesso em: set. 2020.

Acselrad, H. A crítica do "ambiente" e o ambiente da crítica. Revista Antropolítica, 36, 27-47, 2014. doi: 10.22409/ antropolitica2014.0i36

Acselrad, H. Ambientação das lutas sociais: o caso do movimento por justiça ambiental. Estudos Avançados, 24, 68, 103-119, 2010. doi: 10.1590/S0103-40142010000100010

Acselrad, H.; Herculano, S.; Pádua, J. A. A justiça ambiental e a dinâmica das lutas socioambientais no Brasil - uma introdução. In: Acselrad, H.; Herculano, S.; Pádua, J. A. (Orgs.). Justiça ambiental e cidadania. Rio de Janeiro: Editora Relume-Dumará; 2004.

Agostini, R.; Castro, A.M. O que pode o Sistema Único de Saúde em tempos de necropolítica neoliberal? Saúde Debate, 43(8), 175-188, 2019. doi: 10.1590/0103-11042019s813

Andreotti, G.; Freeman, L.E.B.; Shearer, J.J. et al. Occupational pesticide use and risk of renal cell carcinoma in the agricultural health study. Environmental Health Perspectives, 128(6), 067011-1-067011-10, 2020. doi: 10.1289/EHP6334

Anvisa - Agência Nacional de Vigilância Sanitária. Nota Técnica $n^{\circ}$ 23/2018/Sei/Creav/Gemar/Ggtox/Dire3/Anvisa. Processo no 25351.056754/2013-17 (glifosato). Brasília: Anvisa, 2019a. Disponível em: <https://tinyurl.com/y2pmcbk8>. Acesso em: nov. 2020.

Anvisa - Agência Nacional de Vigilância Sanitária. Parecer $n^{\circ}$ 125/2020/SECONS/PFANVISA/PGF/AGU. Brasília: Anvisa, 2020b.

Anvisa - Agência Nacional de Vigilância Sanitária. Parecer técnico de reavaliação $n^{\circ}$ 07, de 2015/GGTOX/Anvisa - 2,4$D$. Brasília: Anvisa, 2015a. Disponível em: $<$ https://tinyurl. com/y26h7pqh>. Acesso em: set. 2020.

Anvisa - Agência Nacional de Vigilância Sanitária. Parecer técnico de reavaliação $n^{\circ} 05$ de 2015/GGTOX/Anvisa Tiram. Brasília: Anvisa, 2015b. Disponível em: <https:// tinyurl.com/y2dnv4wr>. Acesso em: set. 2020.

Anvisa - Agência Nacional de Vigilância Sanitária. Relatório de análise de contribuições em consulta pública - Abamectina. Brasília: Anvisa, 2015c. Disponível em: $<$ https:// tinyurl.com/yyjvp8zu>. Acesso em: set. 2020.

Anvisa - Agência Nacional de Vigilância Sanitária. Resolução de Diretoria Colegiada (RDC) $n^{\circ} 177$, de 21 de setembro de 2017. Brasília: DOU de 22/09/2017, 2017. Disponível em: $<$ https://tinyurl.com/y5xk4rvd $>$. Acesso em: out. 2020. 
Anvisa - Agência Nacional de Vigilância Sanitária. Resolução de Diretoria Colegiada (RDC) $n^{\circ}$ 294, de 29 de julho de 2019. Brasília: DOU de 31/07/2019, 2019a. Disponível em: $<$ https://tinyurl.com/y28en3oq $>$. Acesso em: ago. 2020.

Anvisa - Agência Nacional de Vigilância Sanitária. Resolução de Diretoria Colegiada (RDC) $n^{\circ} 295$, de 29 de julho de 2019. Brasília: DOU de 31/07/2019, 2019b. Disponível em: <https://tinyurl.com/yylestp>. Acesso em: out. 2020.

Anvisa - Agência Nacional de Vigilância Sanitária. Resolução de Diretoria Colegiada (RDC) $n^{\circ}$ 296, de 29 de julho de 2019. Brasília: DOU de 31/07/2019, 2019c. Disponível em: $<$ https://tinyurl.com/y27umeaf $>$. Acesso em: ago. 2020.

Anvisa - Agência Nacional de Vigilância Sanitária. Resolução de Diretoria Colegiada (RDC) $n^{\circ} 428$, de 7 de outubro de 2020. Brasília: DOU de 08/10/2020, 2020a. Disponível em: <https://tinyurl.com/y6fdqfvq>. Acesso em: dez. 2020.

Anvisa - Agência Nacional de Vigilância Sanitária. Resolução de Diretoria Colegiada (RDC) $n^{\circ} 442$, de 2 de dezembro de 2020. Brasília, DOU de 09/12/2020, 2020c. Disponível em: < https://tinyurl.com/y25muerw>. Acesso em: jan. 2020.

Batista, H.G. Exportações do agronegócio devem bater recorde e superar a barreira dos US\$ 100 bi pela $2^{\mathrm{a}}$ vez na história. $O$ Globo, Caderno de Economia [Internet], 04 jan. 2021. Disponível em: < https://tinyurl.com/y9ofnl53>. Acesso em: jan. 2021.

Bernardo, R.G. Internacionalización y la cuestión agraria. Un análisis de las teorías en las sobre internacionalización en el agro mundial y su impacto estructuras de clase nacionales. Trabajo y Sociedad, 21(34), 201-210, 2020. Disponível em: $<$ https://tinyurl.com/y6nfar8b $>$

Brasil. Decreto n. 4.074, de 4 de janeiro de 2002. Brasília: DOU de 2002.

Brasil. Lei no 7.802, de 11 de julho de 1989. Brasília: DOU de 1989.

Brasil. Portaria GM/MS n ${ }^{\circ}$ 888, de 4 de maio de 2021. Brasília: DOU de 2021.

Bombardi, L.M. Carta aberta aos colegas do DG (Departamento de Geografia). São Paulo, 03 mar. 2021.

Carneiro, F.F.; Rigotto, R.M.; Augusto, L.G.S.; Friedrich,
K.; Búrigo, A.C. (Eds.). Dossiê Abrasco: um alerta sobre os impactos dos agrotóxicos na saúde. Rio de Janeiro: Escola Politécnica de Saúde Joaquim Venâncio; São Paulo: Expressão Popular, 2015.

Conama - Conselho Nacional do Meio Ambiente. Resolução Conama/MMA $n^{\circ} 499$, de 6 de outubro de 2020. Brasília: DOU de 09/10/2020, 2020. Disponível em: <https://tinyurl. com/y672qyh9>. Acesso em: dez. 2020.

Fagan, J.; Traavik, T.; Bøhn, T. The Seralini affair: degeneration of Science to Re-Science? Environmental Sciences Europe, 27(19), 2015. doi: 10.1186/s12302-015-0049-2

Friedrich. K. Avaliação dos efeitos tóxicos sobre o sistema reprodutivo, hormonal e câncer para seres humanos após o uso do herbicida 2,4-D. Rio de Janeiro: Fiocruz, 2014. Disponível em: <https://tinyurl.com/y3e7278r > Acesso em: dez. 2020.

Friedrich, K.; Gurgel, A. M.; Augusto, L. G. S.; Sarpa, M.; Bedor, C. N. G.; Gurgel, I. G. D.; Siqueira, M. T. Toxicologia crítica aplicada aos agrotóxicos - perspectivas em defesa da vida. Saúde Debate, 2021. [No prelo.]

Friedrich, K.; Gurgel, A. M.; Sarpa, M.; Almeida, V. E. S.; Gurgel, I. G. D.; Augusto, L. G. S. Registro de agrotóxicos no brasil: um processo enviesado. In: Gurgel, A. M.; Santos, M. O. S.; Gurgel, I. G. D. Saúde do campo e agrotóxicos: vulnerabilidades socioambientais, político-institucionais e teórico-metodológicas. Recife: Ed. Universitária da UFPE, p. 77-107, 2019.

Fiocruz - Fundação Oswaldo Cruz. Fact Sheet $n^{\circ}$ 2. Isenções e reduções fiscais na comercialização, industrialização e uso de agrotóxicos no Brasil. GT de Agrotóxicos. Rio de Janeiro: Fiocruz, 2019a. Disponível em: <https://tinyurl. com/y66ароај>. Acesso em: dez. 2020.

Fiocruz - Fundação Oswaldo Cruz. Nota técnica sobre a proibição da pulverização aérea de agrotóxicos no Ceará. GT de Agrotóxicos. Rio de Janeiro: Fiocruz, 2019b. Disponível em: <https://tinyurl.com/yxggs52y>. Acesso em: dez. 2020.

Foucault, M. As palavras e as coisas: Uma arqueologia das ciências humanas (9a ed.). São Paulo: Martins Fontes, 2007.

Foucault, M. Em defesa da sociedade: Curso no Collège 
de France (1975-1976). São Paulo: Martins Fontes, 1999.

Foucault, M. Microfísica do Poder. Rio de Janeiro: Ed. Graal, 1979.

Garabant, D.H.; Philbert, M.A. Review of 2,4-dichlorophenoxyacetic acid (2,4-D) epidemiology and toxicology. Critical Reviews in Toxicology, 32(4), 233-57, 2002. doi: 10.3109/10408444.2012.710576

Garaj-Vrhovac, V.; Zeljezic, D. Assessment of genome damage in a population of croatian workers employed in pesticide production by chromosomal aberration analysis, micronucleus assay and comet assay. Journal of Applied Toxicology, 22(4), 249-255, 2002. doi: 10.1002/jat.855

Gurgel, A. M. Neurotoxicidade dos agrotóxicos organofosforados e regulação estatal: da indústria da dúvida científica à ocultação de perigo para a saúde humana. Recife, Tese (Doutorado em Saúde Pública) - Centro de Pesquisas Aggeu Magalhães/ Fundação Oswaldo Cruz, 2017.

Gurgel, A. M.; Búrigo, A. C.; Friedrich, K.; Augusto, L. G. S. Agrotóxicos e Saúde. Rio de Janeiro: Fiocruz, 2018.

Gurgel, A. M.; Friedrich, K. Fach Sheet 1: Mudanças na rotulagem e bulas de agrotóxicos e nas diretrizes para classificação, avaliação toxicológica e avaliação de risco dietético. GT de Agrotóxicos da Fiocruz, Rio de Janeiro: Fiocruz, 2020. Disponível em: <https://tinyurl.com/y259y4sj>. Acesso em: dez. 2020.

Gurgel, A. M.; Guedes, C. A.; Gurgel, I. G. D.; Augusto, L. G. S. Reflexos da perda do controle estatal sobre os agrotóxicos no Brasil e sua regulação pelo mercado. Reciis, 11(3), 1-16, 2017. doi: 10.29397/reciis.v11i3.1252

Gurgel, A. M.; Santos, C. C. S.; Alves, K. P. S.; Araújo, J. M.; Leal, V. S. Estratégias governamentais para a garantia do direito humano à alimentação adequada e saudável no enfrentamento à pandemia de Covid-19 no Brasil. Ciência \& saúde coletiva, 25(12), 4945-4956, 2020. doi: 10.1590/1413-812320202512.33912020

Gurgel, A. M.; Teixeira, A. C. A.; Carneiro, F. F. Nota Técnica Fiocruz Ceará [Agrotóxicos]. Fortaleza: Fiocruz, 2015. Disponível em: <https://tinyurl.com/y3m83noh>. Acesso em: out. 2020.

Harvey, D. Para entender o capital: livro 1. São Paulo:
Boitempo Editorial, 2013.

Iarc - Agência Internacional de Pesquisa em Câncer. Agents Classifed by the IARC Monographs, Volumes 1-128. Lyon: Iarc, 2020. Disponível em: <https://tinyurl.com/y4wbckun>. Acesso em: dez. 2020.

Iarc - Agência Internacional de Pesquisa em Câncer. Glyphosate monograps. Lyon: Iarc, 2015. Disponível em: <https:// tinyurl.com/y3ucw959>. Acesso em: ago. 2020.

Iarc - Agência Internacional de Pesquisa em Câncer. Monographs on the evaluation of carcinogenic risks to humans. DDT, Lindane and 2,4-D. Lyon: Iarc, 113, 2017. Disponível em: $<$ https://tinyurl.com/yyvl5oqo>. Acesso em: nov. 2020.

Kozicki, K.; Chueiri, V. K. Impeachment: a arma nuclear constitucional. Lua Nova, 108, 157-176, 2019. doi: 10.1590/0102-157176/108

Krimsky, S.; Gillam, C. Roundup litigation discovery documents: implications for public health and journal ethics. Journal of Public Health Policy. 39(3), 318-26, 2018. doi: 10.1057/s41271-018-0134-z

Lobato, L.V.C.; Costa, A.M.; Rizzotto, M.L.F. Reforma da previdência: o golpe fatal na seguridade social brasileira. Saúde Debate, 43(120), 5-14, 2019. doi:10.1590/01031104201912000

Mapa - Ministério da Agricultura, Pecuária e Abastecimento. Instrução Normativa ${ }^{\circ} 13$, de 8 de abril de 2020. Brasília: DOU de 09/04/2020. 2020b. Disponível em: <https://tinyurl. com/y472zn95>. Acesso em: nov. 2020.

Mapa - Ministério da Agricultura, Pecuária e Abastecimento. Portaria $n^{\circ} 43$, de 27 de fevereiro de 2020. Brasília: DOU de 27/02/2020. 2020a. Disponível em: $<$ https://tinyurl.com/ y2eph5s9>. Acesso em: nov. 2020.

Mapa - Ministério da Agricultura, Pecuária e Abastecimento. Portaria $\mathrm{n}^{\circ} 201$, de 24 de junho de 2020. Brasília: DOU de 25/06/2020. 2020c. Disponível em: <https://tinyurl.com/ y3a57nkw>. Acesso em: out. 2020.

Marques, L. Capitalismo e colapso ambiental. 3 ed. São Paulo: Ed. Unicamp, 2018.

Mbembe, A. Necropolítica: biopoder, soberania, estado de exceção, política da morte. São Paulo: N-1 edições, 2018. 
McHenry, L.B. The Monsanto Papers: Poisoning the scientific well. International Journal of Risk \& Safety in Medicine, 29(3-4), 193-205, 2018. doi: 10.3233/JRS-180028

Michaels, D. Doubt is their product: how industry's assault on science threatens your health. New York: Oxford University Press, 2008.

Miligi, L.; Constantini, A.S.; Veraldi, A. et al. Cancer and pesticides: an overview and some results of the Italian multicenter case-control study on hematolymphopoietic malignancies. Annals of the New York Academy of Sciences, 1076, 366-377, 2006. doi: 10.1196/annals.1371.036

MS - Ministério da Saúde. Revisão do Anexo XX da Portaria de Consolidação $n^{\circ}$ 5, de 28 de setembro de 2017 do Ministério da Saúde (antiga Portaria MS No 2914/2011), Tema II - Padrão de Potabilidade e Planos de Amostragem, Substâncias Químicas - Agrotóxicos, Substâncias não contempladas na PRC no 5/2017 e selecionadas para avaliação - Parte I e Parte II, Subsídios para Discussão e Orientações para Revisão. Brasília: Ministério da Saúde, 2020.

Mustafá, M.A.S.M; Anselmo, G.C.R.; Silva, S.S. Democracia e justiça social em tempos de golpe sob a égide do neoliberalismo. Revista Katálysis, 21(2):416-426, 2018. doi: 10.1590/1982-02592018v21n2p416

OPAS - Organização Pan-Americana de Saúde. Folha informativa - COVID-19 (doença causada pelo novo coronavírus), 2020. Disponível em: <https://tinyurl.com/ rz9mdv6>. Acesso em: dez. 2020

Ortega, F.; Orsini, M. Governing Covid-19 without government in Brazil: Ignorance, neoliberal authoritarianism, and the collapse of public health leadership. Global Public Health, 15(9), 1257-1277, 2020. doi:10.1080/17441692.2 020.1795223

Park, S.K.; Kang, D.; Beane-Freeman, L. et al. Cancer incidence among paraquat exposed applicators in the agricultural health study: prospective cohort study. International Archives of Occupational and Environmental Health, 15(3), 274-81, 2009. doi: 10.1179/oeh.2009.15.3.274

Parlamento Europeu. Directiva 2009/128/CE do Parlamento Europeu e do Conselho, de 21 de outubro de 2009, que estabelece um quadro de acção a nível comunitário para uma utilização sustentável dos pesticidas. Jornal Oficial da
União Europeia, 309, 71-86, 2009. Disponível em: <https:// tinyurl.com/y6z8uxnf>. Acesso em: out. 2020

Paulani, L. Acumulação sistêmica, poupança externa e rentismo: observações sobre o caso brasileiro. Estudos Avançados, 27(77), 237-264, 2013. doi: 10.1590/S010340142013000100018

Pelaez, V.; Terra, F.H.B.; Silva, L.R.A regulamentação dos agrotóxicos no Brasil: entre o poder de mercado e a defesa da saúde e do meio ambiente. Revista de Economia, v. 36, n. 1, 2010. Disponível em: $<$ https://revistas.ufpr.br/economia/ article/download/20523/13714> . Acesso em: mai. 2021.

Reis-Filho, J.A.; Quinto, D. Covid-19, Afastamento social, pesca artesanal e segurança alimentar: como esses temas estão relacionados e quão importante é a soberania dos trabalhadores da pesca diante do cenário distópico. SciELO 2020 [preprint]. doi: 10.1590/SciELOPreprints. 54

Rosa, A.C.S.; Gurgel, A.M.; Friedrich, K. Presença de agrotóxicos em água potável no Brasil: Parecer técnico do GT de Agrotóxicos da Fiocruz para a Revisão do Anexo XX da Portaria de Consolidação $\mathrm{n}^{\circ}$ 05, de 28 de setembro de 2017 do Ministério da Saúde, para o parâmetro "agrotóxicos". Rio de Janeiro: Fiocruz, 2020.

Salam, S.; Arif, A.; Mahmood, R. Thiram-induced cytotoxicity and oxidative stress in human erythrocytes: an in vitro study. Pesticide Biochemistry and Physiology, 164, 14-25, 2020. doi: 10.1016/j.pestbp.2019.12.003

Milanez, B.; Santos, R.S.P. Neoextrativismo no Brasil? Uma análise da proposta do novo marco legal da mineração. Revista Pós Ciências Sociais, v. 10, p. 119-148, 2013. Disponível em: <https://www.ufjf.br/poemas/files/2014/07/ Milanez-2013-Neoextrativismo-no-Brasil.pdf $>$. Acesso em: mai. 2021.

Sanctis, A.; Mendes, C.H. O ataque à liberdade acadêmica no Brasil. Quatro Cinco um, 01 jun. 2020. Disponível em: $<$ https://www.quatrocincoum.com.br/br/artigos/1/o-ataque-a-liberdade-academica-no-brasil>. Acesso em: dez. 2021.

Santos, F.; Szwako, J. Da ruptura à reconstrução democrática no Brasil. Saúde Debate, 40(spe), 114-121, 2016. doi: 10.1590/0103-11042016S10

Schneider, S.; Cassol, A.; Leonardi, A.; Marinho, M. M. Os 
efeitos da pandemia da Covid-19 sobre o agronegócio e a alimentação. Revista Estudos Avançados, 34(100), 167-188, 2020. doi: 10.1590/s0103-4014.2020.34100.011

Sears, M.; Walker, C.R.; Van der Jagt, R.H.C.; Claman, P. Pesticide assessment: Protecting public health on the home turf. Paediatrics and Child Health, 11(4), 229-234, 2006. Disponível em: $<$ https://tinyurl.com/y 7 tlmuse $>$. Acesso em: mai. 2021.

Souza, M.; Gurgel, A.M.; Fernandes, G.; Melgarejo, L.; Bittencourt, N.; Friedrich, K. Agrotóxicos e transgênicos: retrocessos socioambientais e avanços conservadores no Governo Bolsonaro. Revista da Anpege, 16(29), 319-352, 2020. doi: 10.5418/ra2020.v16i29.12561

STF - Supremo Tribunal Federal. Inquérito 4831. Número Único 0024271-86.2020.1.00.0000. Origem: DF - Distrito Federal; Relator: Ministro Celso de Mello; Autor: Ministério Público Federal; Investigado: Jair Messias Bolsonaro. Brasília: STF, 2020.

Tangamornsuksan, W; Lohitnavy, O.; Sruamsiri, R. et al. Paraquat exposure and Parkinson's disease: A systematic review and meta-analysis. Archives of Environmental \& Occupational Health, 74(5), 225-238, 2019. doi: 10.1080/19338244.2018.1492894
Unicamp - Universidade Estadual de Campinas. Posicionamento Público do Departamento de Saúde Coletiva (DSC) da Faculdade de Ciências Médicas (FCM) da Universidade Estadual de Campinas (Unicamp) sobre matéria divulgada pela ONG Repórter Brasil em 15/07/2020 “Lobby usa pesquisa não concluida para pressionar Anvisa sobre agrotóxico proibido”. Campinas: Unicamp, 2020. Disponível em: $<$ https://tinyurl.com/y5cusfaw $>$. Acesso em: dez. 2020.

Wallace, R. Pandemia e agronegócio: doenças infecciosas, capitalismo e ciências. São Paulo: Editora Elefante, 2020.

Wang, Z.; Tang, K. Combating Covid-19: health equity matters. Nature, 26, 458, 2020. doi: 10.1038/s41591-0200823-6

Wenham, C.; Smith, J.; Morgan, R. Covid-19: the gendered impacts of the outbreak. Lancet, 395, 846-8, 2020. doi: 10.1016/S0140-6736(20)30526-2

Yi, S.-W.; Ohrr, H.; Hong, J.-S.; Yi, J.-J. Agent Orange exposure and prevalence of self-reported diseases in Korean Vietnam veterans. Journal of Preventive Medicine and Public Health, 46(5)213-25, 2013. doi: 10.3961/jpmph.2013.46.5.213 